\title{
The ASEAN-China Free Trade Area: Neighbors, Relatives or Foes?
}

\author{
Jingjia $\mathrm{Ke}^{*}$
}

The Framework Agreement for the ASEAN-China Free Trade Area was initiated in 2002. It is the first ASEAN Plus pattern free trade agreement in East Asia. To understand the cultural and historical bonds between China and Southeast Asian States, and contemporary Chinese regional political economy in building the ACFTA, this paper reviews the tributary trade and ancient Chinese diplomacy between China and the neighboring States. The primary purpose of this research is to show how the ACFTA is in the interests of all parties in the course of China's fast economic and political growth. The following article highlights the ACFTA provisions by examining trading agreements in goods, services and investment in the context of the corresponding WTO provisions. In the end, it suggests the possible resolutions for achieving a win-win and interdependent ASEAN-China Free Trade Area.

Keywords: ACFTA, ASEAN-China, Tributary Trade, Early Harvest Program, Agreement on Trade in Goods, Agreement on Trade in Services, Agreement on Trade in Investment

\section{INTRODUCTION}

"Preferential trading arrangements" have proliferated in many regions of the contemporary international community. They have become accepted as the second-best option after the Most Favoured Nations ("MFN") rules under the WTO framework. In East Asia, particularly, the mechanism of the ASEAN-China FTAs, initiated in 2002, reflected widespread anxieties about the uncertainty of the WTO trade negotiations that catalyzed the spread of 'ASEAN Plus' mechanisms. 
While China is shaping the China-ASEAN maritime cooperation, the parties to the agreement have progressively liberalized trade in goods, services and investment by signing a series of agreements that were launched by the first Framework Agreement between the ASEAN and China (hereinafter ACFTA Framework). ${ }^{1}$ Statistics published by the Ministry of Commerce of the People's Republic of China ("PRC") from 2000 to 2009 shows that the average annual growth rate in goods trade was over 20 percent. ${ }^{2}$ Accordingly, China-ASEAN bilateral trade has surged sharply from USD 54.77 billion in 2002 to USD 400.1 billion in 2012, with an average annual growth rate of 22 percent. $^{3}$

Under the ACFTA Framework, extensive economic and political cooperation has been initiated, ranging from senior ministerial meetings to private business exchanges. ${ }^{4}$ Chinese officials expected that the ACFTA would be the third biggest world economic bloc in light of large consumption of a population of two billion. ${ }^{5}$ In 2009, the ASEAN finally became China's third largest import market. ${ }^{6}$ Likewise, China is the third leading import market for the ASEAN after the EU and the US. ${ }^{7}$

However, as China did not have a long tradition of pursuing her economic and political interest through international law, building the ACFTA was the first testing ground for her growing economic influence under the WTO. In the ASEAN, many are skeptical of the ASEAN-China commerce, as statistics show the trade deficits of China with the ASEAN in 2011, which was the second year for completing the ACFTA among the ASEAN-6 and China, reached USD 22.63 billion $^{8}$ and China's trade benefits from the ASEAN (USD 1.787 billion) was considerably smaller than that of the ASEAN's (USD 2.986 billion). ${ }^{9}$ These high trade deficits indicate that the ACFTA is not a purely market-oriented trade policy, but primarily a politically oriented FTA aiming at easing tensions in neighboring overlapping and competing markets. ${ }^{10}$

The primary purpose of this research is to show how the ACFTA is in the interests of all parties in the course of China's fast economic and political growth. This paper is composed of seven parts including short Introduction and Conclusions to discuss why China choose the ASEAN as its 'first front' in its trade liberalization efforts and how the ACFTA is in the interests of all parties in the course of China's fast economic and political growth. Part two will explore the historical, political and economic initiatives in building the ACFTA to show 
that ideology of "giving with a little taking" originating from the tributary trade still characterizes current trade arrangement between the ASEAN and China. While the ASEAN members benefited from generous terms of access to Chinese markets, they have been guaranteed the security of a benevolent and harmonious tributary interdependent with China. The following three parts of this article will review the trading agreements in goods, services and investment to indicate how the Party has incorporated and optimized the WTO provisions in the ACFTA. Part six will assess the challenges and obstacles ahead in achieving a win-win situation and interdependent ASEAN-China FTA in the process of East Asian regional integration.

\section{BUILDING THE ACFTA}

The ACFTA is based on the traditional Chinese world order called 'tribute system,' which can be defined as "the Sino-centric hierarchy world order as one in which China possessed the superior internal, central and higher power based on its cultural and ethnic ascendancy, while dependent members of China, who were attracted by the virtuous conduct of the Emperor of the Middle Kingdom." "According to Professor Wang Tieya, the relationship between China and its neighbors was not based on the concepts of sovereignty and equality of international law, but was retained in the Confucian doctrine of benevolence and obedience. $^{12}$ In Wang's view, the tribute system became a crucial institution and a manifestation of the Chinese traditional world order. ${ }^{13}$ It is also emphasized that unlike modern Westphalian view of equality among sovereign States, the tribute system was governed by diplomatic and political contacts and cultural and economic relationships between two or more unequal asymmetric and interdependent 'superior/inferior' political units. ${ }^{14}$

\section{A. Similarity between the Tributary Rules and Essential Features of the ACFTA}

In fact, for most nations in Southeast Asia, tributary relations immediately entitled all recipients profitable trade and rights of entry to the Middle Kingdom (China). ${ }^{15}$ Traditionally, tributary trade in Asia was a Chinese-essential international trade 
principle, which laid down the ancient 'MFN' rules in the Chinese order. The rights of trade with local Chinese and the preferential free-duty trade policy were openly and indiscriminately granted to the tribute envoy and merchants from the tribute ship at Beijing and at all frontiers. ${ }^{16}$ Most importantly, any imports in the tributary ship and any imperial gifts in return would be exempt from tax. ${ }^{17}$ Thus, merchants could enjoy the trading privileges conferred by the Chinese court and were even entitled to the right of exchange of its own non-tributary goods in the Chinese market. ${ }^{18}$

There are thus similarities between the unilateral and generous tributary rules and a tentative contemporary Chinese MFN principle in pursuing political rather than economic ends. From the sketch of the Sino-centric history of trade above, it reflects that China has been under the shadow of "giving with little taking" of ancient Chinese benevolent trade patterns in the ACFTA shown at the Early Harvest Programme ("EHP") and the China-Hong Kong Closer Economic Partnership Agreement ("CEPA"). ${ }^{19}$ Ewing-Chow points out that the EHP of the ACFTA can be seen as a 'unilateral gift' offered by China to the ASEAN in which China agreed on the concessional tariff reductions on agriculture products and preferential treatment on 130 manufactured goods. By offering special treatment and development assistance for Cambodia, Laos, Myanmar and Vietnam ("CLMV"), the extension of the WTO benefits to the non-WTO members of the ASEAN, as well as the "WTO-plus' liberalization ${ }^{20}$ of the ASEAN exports to China, enabled the Association to be "the first explorer" in seeking opportunities from the Chinese market. ${ }^{21}$ Additionally, the ASEAN and China have extended FTAs beyond the traditional WTO sectors to incorporate broad sectors of intellectual property, trade facilitations and agricultural cooperation. ${ }^{22}$

\section{B. Building a Good Neighborhood and Nurturing Mutual Trust}

The tributary trade contributed not only to the flourishing of trade interaction in East Asia, but also to the flood of Chinese culture and Chinese migrants into Southeast Asia. By controlling a substantial part of the economy, ranging from manufacturing to wholesale and real estate, ethnic Chinese have had a strong influence on the economic growth of Southeast Asia. ${ }^{23}$ These ethnic Chinese migrants were called 'Nanyang Chinese' and have contributed their great talents and enormous treasures to China from the late nineteenth century. ${ }^{24}$ In recent 
decades, ethnic Chinese in Southeast Asia have continued to offer an invaluable contribution to a market-oriented China and economic and political initiatives to the ACFTA. As a reward, China opened its market widely to Southeast Asians of Chinese descent.

China recognized the legal identity of the ASEAN from the late 1970s and opened its domestic market to the ASEAN States, especially Southeast Asians of Chinese descent, who were treated as kin and were able to engage more easily than other foreigners in the wave of economic development in China. ${ }^{25}$

Southeast Asian States have developed diplomacy of balance to engage China while retaining their military and defense links with the US. ${ }^{26}$ It is also noted that for China, the main reasons for lobbying the ASEAN are to alleviate the perception that China is a threat, and to compete with Japan and the US for regional security and influence. ${ }^{27}$ Initiating the ACFTA served Chinese political and strategic motivation in a number of ways: (1) Chinese leaders need a favourable and stable economic environment after accession to the WTO, which was essential for sustaining domestic reforms and political stability; ${ }^{28}(2)$ the ACFTA stabilized China's neighbourhood so that it could build a better political environment for economic growth. ${ }^{29}$

In an economic sense, the RTA could help to increase the regional influence of the ASEAN States by pooling their resources and combining markets. ${ }^{30}$ In November 2002, by signing the Framework Agreement on Comprehensive Economic Cooperation (hereinafter Framework Agreement), the ASEAN and China turned the page onto a new era of bilateral economic cooperation that involved comprehensive legal guidelines for establishing ACFTA by 2010 for the ASEAN-6, and by 2015 for newcomers. ${ }^{31}$ For both Parties, it was a first attempt to taste the rewards of regional trading arrangements beyond the WTO. Their amiable cooperation was demonstrated in the Preamble as: ' $W e[\ldots]$ collectively ASEAN [...] and China. ${ }^{32}$

To show her goodwill and sincerity, China offered additional market accesses of recourse-based products to the ASEAN-4 including grain, oil and timber, and decreased the tariffs and NTBs of manufacturing equipment and motor vehicles. ${ }^{33}$ Besides, China has offered substantial contributions to gauge the economic pulse of most Southeast Asian and gained mutual benefits from an exchange of resources in its infrastructural hunger for highways, bridges and ports. ${ }^{34}$ 
The ASEAN-China relations and cooperation had been developed in an intimate relations that benefits from their historical, ethnic and commercial links. From diplomatic and dialogue cooperation to high-level regional trade collaboration, the Parties have shown their complete trust in the legal instruments established. In addition, a new Chinese regionalism, in the form of the ACFTA, might partially echo the very heart of the benevolent tributary practice of the past which aimed to ensure internal stability and prosperity through buying the stabilization of China's external environment from its surrounding States. ${ }^{35}$ In conclusion, the ASEAN obtained the rights of admission to the Chinese market in exchange for recognition by China.

\section{The Trade in Goods Agreement}

The ACFTA Framework Agreement defines the main coverage of cooperation between the ASEAN and China in trade, services and investment. ${ }^{36}$ To this end, three sequential agreements have been negotiated to signify the progress that both parties have made in building the ACFTA: the Agreement on Trade in Goods ("TIG") on November 29, 2004, the Agreement on Trade in Services ("TIS") on January 14, 2007 and the Agreement on Trade in Investment on August 15, 2009. One of the remarkable features of these three agreements in the ACFTA is the coverage of products and trade liberalization that go beyond the WTO agreements. In light of the features and principle provisions of these agreements under the ACFTA framework, China and the ASEAN might gradually present a symbolic model of FTAs for other trade partners in the region, which are under the influence of "giving with a little taking" of ancient Chinese benevolent trade patterns.

\section{A. Comprehensive FTAs with a Broad Range of Product Coverage}

The Framework Agreement recalled China's 2001 proposal to establish the ACFTA within ten years, with a tariff reduction or elimination program in place by 2010 for the ASEAN-6 and by 2015 for CLMV and an EHP in which the list of products and services would be determined by mutual consultation. ${ }^{37}$ It was estimated that, upon China's accession to the WTO, the demand for food, energy, raw materials and intermediate products would increase by USD 13.3 billion between 2000 and $2005 .{ }^{38}$ Most provisions under the ACFTA were designed in 
the context of the WTO. E.g., the commitments under Articles 3 and 6 are to be fulfilled according to the WTO requirements on tariff reduction. ${ }^{39}$ Tariffs and nontariff barriers in substantially all trade would be progressively eliminated in the ACFTA, which are categorized into the following three tracks as the normal track, the sensitive track and the early harvest track. ${ }^{40}$

A distinct feature of the ACFTA, the EHP allows the Parties to enjoy the early benefits of the ACFTA by implementing the reduction and elimination of tariffs on a large number of agricultural products by no later than January 1, 2004. ${ }^{41}$ Before the FTA was entered into force, the participating parties could enjoy concessions tariffs on 600 agricultural goods and manufacturing and industrial products, ranging essentially from meat, fish, fruit and vegetables to dairy products. ${ }^{42}$ There are three streams of products in the EHP. ${ }^{43}$ Among which, agricultural products are the sensitive sector in bilateral negotiations between China and individual ASEAN Members. In this area, China has made many concessions to seal the deal and harmonize differences among the ASEAN-10 countries. E.g., Thailand was enthusiastic about the Sino-ASEAN agro-food liberalization and had started negotiations with China prior to full discussions of other ASEAN Members. ${ }^{44}$ Although the two-way trade under the EHP accounted for only 2 percent of total China-Thai trade, the Thai government expected that it would capture the 'firstmover' advantage in the large Chinese market via bilateral trade. ${ }^{45}$ Eleven months after October 2003, the day when China and Thailand launched the enforcement of tariff reductions on 188 different categories of fruit and vegetables, inter-trade of those products between the Parties reached USD 0.57 billion and increased 120 per cent compared to figures before the formation of the ACFTA. ${ }^{46}$

Wang reveals that China has made unilateral concession to the ASEAN members since all products imported to China can fall under the preferential EHP schemes, while not all products exported to the ASEAN from China can enjoy corresponding the EHP benefits. ${ }^{47}$ The ratio of tariff concessions of China and the ASEAN-6 have been reciprocated in Annexes 1 and $2 .^{48}$ In the case of Indonesian exports to China, out of total exports of USD 3.6 billion, 48.4 percent of trade is covered by the reciprocal concessions. Similarly, Thailand receives as much tariff preferences as Indonesia with 42.9 percent of total trade equivalent to USD 5.6 billion. The tariff concessions rate of the goods from Malaysia is 12.1 percent of the exports to China. In case of China, only 15.2 percent exports to 
the ASEAN can enjoy the reciprocal concessions that are relatively lower than the tariff concessions ratio of the ASEAN-6. The asymmetric trading between the ASEAN-6 and China reflects that the generous concessions made by China follow the ancient Chinese trade diplomacy of "giving with a little taking."

\section{B. Legal Arrangement beyond the WTO Provisions}

The Framework Agreement and the preceding Agreement on Trade in Goods, draw upon the relevant WTO commitments and contains provisions that go beyond the WTO framework. The Framework Agreement reaffirms the rights, obligations and undertakings of the respective parties under the WTO and other bilateral, multilateral and regional agreements in its Preamble. The Parties agreed to fulfil the WTO commitments to eliminate tariffs on substantially all the trade covering from the products in the normal, sensitive and the EHP track. ${ }^{49}$

The Trade in Goods Agreement not only inherited the essence of the Framework Agreement, but also incorporated most of the WTO provisions. It laid down the basic rules in Article 2 of the Framework Agreement. ${ }^{50}$ The Trade in Goods Agreement incorporates all integral parts of other WTO principles and measures, such as the principle of transparency in Article X of GATT 1994, General Exceptions under Article XX of GATT, non-tariff measures, safeguard measures, subsidies and countervailing, and anti-dumping measures. ${ }^{51}$

The Trade in Goods Agreement thus essentially adopts the relevant WTO disciplines in Article 9(1) with some variations. Article 9 allows the Parties to initiate the safeguard measures on imported products within the transition period. ${ }^{52}$ Under the ACFTA, the safeguard measures can apply for no more than five years, which is below the duration under the WTO rules since the WTO member can extend the application of safeguard measures over the period of eight years. ${ }^{53}$ Wang notes that one of the aims of the ACFTA is to eliminate the safeguard measures within a short period of time. ${ }^{54}$

Articles 8 and 9 are also designed in a unique ASEAN-China FTA way that crosses the boundaries set by the WTO rules, but is still under massive influence of the WTO law. The safeguard measures that fall under the quantitative restrictions set up in Article 5 of the WTO safeguard measures are explicitly excluded by Article 9, paragraph 7 of the TIG Agreement. E.g., quotas, that are currently allowable under the Article 5 of the WTO safeguard measures, are 
constrained under the ACFTA safeguards measures which prohibits any Party from drawing on quantitative restriction at any time unless otherwise provided under the WTO rules. Most importantly, the provisions clarify that when the ACFTA measures apply, a party cannot have recourse to the WTO safeguard measures simultaneously. ${ }^{55}$ It provides a defined mechanism for the conflicts arising between the safeguard measures and the relevant ACFTA provisions. Unsurprisingly, China has granted those favorable ACFTA safeguards measures to all the ASEAN Member States including the non-WTO members at the time.

\section{Recognition of China's Market Economy Status}

Apart from the above basic trade measures, one of the remarkable victories for China is the recognition of China's full "market economy status" ("MES") in Article 14 of the TIG Agreement. By acknowledging China's MES, the ASEAN has discarded the unfair method of measuring dumping with the benchmark of price and economic status. The ASEAN is the first trading Party to reject these anti-dumping measures in Articles 15 and 16 of the Protocol of Accession Agreement and Paragraph 242 of the Working Party Report on the Accession of the PRC to the WTO. According to these clauses, the WTO members can set trade remedies measures against China, such as safeguard measures and the quantitative restrictions, for a specific period of time. ${ }^{56}$ Article 15(a)(i) of the Protocol of Accession Agreement states that:

If the producers under investigation can clearly show that market economy conditions prevail in the industry producing the like product with regard to the manufacture, production and sale of that product, the importing WTO Member shall use Chinese prices or costs for the industry under investigation in determining price comparability;...

If the producers can establish the market economy conditions prevailing in the manufacture, production and sale of a product, Chinese prices or costs can be used in determining whether the overseas prices of their goods are below those paid in China, and therefore fall under the Anti-dumping Agreement and Subsidies and Countervailing Measures Agreement. When MES is recognized by members of the WTO, China's product prices can be thus used as the sole method to measure the margin of dumping, which is usually difficult to establish in anti-dumping investigations. 
To determine the extent of dumping, first of all, it needs to be established that the said goods have been sold at "less than fair value" by comparing import prices with domestic prices. ${ }^{57}$ Further, based on the methodologies above, Chinese prices and costs would be taken into consideration in measuring dumping if the producer establishes that the market economy conditions prevails in the Chinese industry. ${ }^{58}$ Instead, the investigators may apply the prices and costs from a nonmarket economy 'surrogate country,' selected from the countries with similar level of economic development. ${ }^{59}$ Thus, the margins of dumping vary according to the country against which it chooses to estimate the costs of production. These standards for measuring dumping can turn out to be an arbitrary and subjective mode of selection. Accordingly, under the present anti-dumping system, the countries in non-market economies are vulnerable and likely to be targeted by dumping litigation.

The anti-dumping law is plainly based on price discrimination, which may not have harmful and distorted effects on the domestic market, especially when a lower price is commonly used in offering discounted prices in a competitive international market. ${ }^{60}$ Therefore, marginal price discrimination should be permissible unless the objectives of applying low prices are substituting and monopolizing the host country's market. Meanwhile, there is the tendency for the WTO members to rely heavily on these ambiguous anti-dumping actions as a substitute for traditional trade barriers to protect their domestic firms and offset losses from their foreign imports. ${ }^{61}$ As a result, the primary means to correct unfair market behavior in competition has been the outright abuse of anti-dumping measures, not the pursuit of fair market value.

Nonetheless, New Zealand is aware that these methods for measuring dumping are ambiguous and has offered the MES to China in their 2004 FTA negotiations. ${ }^{62}$ As China has achieved steadily growing economic power on the international stage for the eleven years since joining the WTO, more and more countries have followed the ASEAN and New Zealand in recognizing China's MES in bilateral trade arrangements. ${ }^{63}$ Based on the recent China's bilateral FTAs, the recognition of China's market economy status has been regarded as an essential element in concluding an FTA with China.

China and the ASEAN leaders have evolved an alternative trade pattern and regionalism model for the south-south trading to the region, which was 
signified in the concessions China made in the EHP, its compliance with the basic WTO principles and the recognition of China's MES. Most importantly, the collaborations shown in the Trade in Goods Agreement also implies that China's Southeast Asian partners have accepted and recognized China's economic hegemony in return for the ASEAN's regional recognition. These complex features of the ASEAN-China trade and its ever increasing trade volume indicate the structural changes in their economies, where China is rising as the new economic driver in Asia, while the ASEAN sustains China's growth and acts as suppliers for China's booming economy.

\section{The Trade in Services Agreement}

The impact of China's accession to the WTO has been far-reaching across East Asia. The ASEAN member States, such as Vietnam and Indonesia, have benefited most from the structural changes of China, since their labor-intensive markets that previously used to compete with China were tending to shift to highend manufacturing industries. ${ }^{64}$ Recent reports have affirmed that there have been larger gains in trade from services exported to China and from industries such as aviation, logistics, tourism and finance, which increased sharply with the ever-growing demands of the middle-class in China. ${ }^{65}$ Presumably, these potential services gains will benefit the more advanced ASEAN States that have concentrated on high-end manufacturing industries, such as Singapore, Malaysia, Thailand and the Philippines.

The ASEAN-China Trade in Service Agreement (hereinafter TIS Agreement) was signed on January 14, 2007 under the Framework Agreement, which is China's first FTA in services. In the preamble to the TIS Agreement, ${ }^{66}$ the Parties, reiterating Article 4 of the Framework Agreement, promised to progressively liberalize and eliminate substantially all discrimination in services, and to expand the depth and scope of service trade with substantial sectoral coverage beyond those undertaken of the Parties under the WTO General Agreement on Trade in Services ("GATS"). Although the TIS Agreement excluded services such as government procurement and government-related services within the meaning of Article 2(2), the scope of liberalization in services are still substantial and 
abundant, ranging from computer-related services, tourism and travel services to telecommunication and energy. ${ }^{67}$ In addition, the TIS Agreement provides more than 60 additional subsectors of services committed by the ASEAN Member States which are parties to the GATS. ${ }^{68}$ The Parties have even consented to and mutually recognized the educational qualifications, experience obtained, licenses, and certifications granted in another party. ${ }^{69}$ With respect to the CLMV members, as in the Framework Agreement, special and differential treatment and flexibility are accorded to them in Article 17 of the TIS Agreement through specific negotiated commitments. ${ }^{70}$

The Service Agreement was designed on the GATS model. The TIS adopted the GATS four "modes of supply," which are cross-border (mode 1); consumption abroad (mode 2); commercial present (mode 3); and presence of natural persons (mode 4), defined in the GATS Article 1(2) as the basis for scheduling commitments. $^{71}$ Other key principles of the GATS - transparency (Article 3) and the disclosure of confidential information (Article 4), as well as the GATS Annexes on the Movement of Natural Persons Supplying Service, Air Transport Service, Financial Service and Telecommunications Services (Article 28) - were directly incorporated in and formed integral parts of the TIS Agreement. With regard to liberalizing trade in services, the key element is the removal of domestic legislative restrictions and unnecessary barriers to foreign services and suppliers, such as measures relating to qualification requirements and procedures, technical standards and licensing requirements. To this end, pursuant to Article VI(4) of the GATS, the Parties promised to review and update relevant disciplines on these measures. ${ }^{72}$ The Service Agreement follows the GATS and schedules specific commitments agreed by the Parties with respect to market access and national treatment in Part III.

China has matured in its negotiation techniques with the 10 ASEAN members over the issues of trade in services by arranging a set of pure GATS-style positive list of specific commitments that are subject to limitations of market access and national treatment. ${ }^{73}$ This Agreement has adopted the positive lists of the WTOstyle GATS that have been widely used and are familiar with many ASEAN members and China. ${ }^{74}$ Basically, it can be regarded as a multilateral agreement that China made a single schedule of specific commitments to all the ASEAN States, while each ASEAN country retains her individual schedule of specific 
commitments with China and the rest of the ASEAN Member Countries. ${ }^{75}$ Here, China and the ASEAN members have all negotiated specific deals in separate agreements. Unlike the TIG Agreement that is performed by reducing tariffs in sensitive agricultural products, preferential agreements in services are usually related to intangible goods and the removal of regulatory restrictions on foreign services at the domestic level. ${ }^{76}$ As a result, each Party might face more pressure from domestic service providers to change its relevant domestic measures in service. Additionally, in comparison with negative list approach, the four-mode positive list tends to leave to the discretion of each Party market access and national treatment in sectors that are not subject to the limitations and conditions inscribed in the TIS. Another main reason for the loose approach in the positive list was that both the ASEAN members and China are not confident of their domestic regulatory regime, which could retain more restrictive measures than an advanced negative list.

On the application and extension of commitments in the TIS Agreement, China and the rest of the ASEAN member States agreed to apply each other's individual schedule of specific commitments on a reciprocal basis. ${ }^{77}$ That means the Parties are free to tailor the sector coverage and substantive content of commitments in the Schedule. In line with Article 21, specific commitments are undertaken in the following five sectors as the time-frame for implementation, the sector or sub-sector of the commitments, limitations on market access that are captured by Article 18, conditions and qualifications on national treatment, and undertakings of additional commitments. Some countries, such as Vietnam and Singapore, liberalized service sectors in the Schedule ranging widely from telecommunication, financial, health, education and environmental services, while other countries, such as Brunei, Laos and Myanmar, have placed no more than three sectors in the first package, which focuses on transport and tourism. Eight ASEAN members specify a GATS-plus commitment in tourism, most of which are related to unbound measures on market access and national treatment on cross-border supply and consumption abroad. ${ }^{78}$ Countries like the Philippines put forward minimum payment requirements for operating tourist-related services on commercial presence. ${ }^{79}$ Countries with abundant natural resources, like Indonesia and the Philippines, provided specific commitments on energy services; The Philippines commit on services related to power generation and the supply of 
energy, while Indonesia does on coal liquefaction and coal gasification services. ${ }^{80}$

As the concessional tariff scheme developed since the EHP, China unilaterally extended a single schedule of special commitment to all ASEAN Member States, while each ASEAN State could preserve its specific commitments to China and other members via individual service arrangements. ${ }^{81}$ China undertook specific commitments in five GATS-plus sectors (business, construction, environmental, cultural and sporting, and transport services) and made a favorable commitment to the sector of construction, which has been regarded as a significant trade barrier for western countries to enter the Chinese market. ${ }^{82}$ In addition, the limitations in the TIS are less restrictive than those undertakings China has committed to under the GATS. E.g., China's commitment in the service for wholly foreign-owned enterprise is permissible in the TIS, while the commitment for joint ventures with foreign majority ownership under the GATS is still restrictive. ${ }^{83}$

In conclusion, the Service Agreement between the ASEAN countries extensively mirrored and expanded the essential principles of the GATS. All parties have shown an unprecedented passion to explore abundant GATS-plus specific commitments in the TIS first package. By and large, China's negotiation skills and legislative techniques are becoming more mature on adopting the commonly used positive list and scheduling with each party a whole range of commitments with regard to the removal of domestic legislative restrictions and unnecessary barriers to foreign services and suppliers.

\section{The Trade in Investment Agreement}

The mutual investment between the ASEAN countries and China has transformed the local domestic investment markets into an integrated and complementary one which has attracted the ASEAN, China and other international enterprises to the region. The ASEAN countries can benefit from the advantages of the openingup of China and huge domestic investment opportunities. In turn, China's 'going out' strategy has energized State-owned enterprise investing abroad, which has changed the pattern of comparative advantage between the region and China. On August 15, 2009, China signed its first preferential investment agreement with the ASEAN. 


\section{A. Is China Squeezing the ASEAN FDI Inflows?}

It was not until five years after signing the Trade in Goods Agreement, through rounds of negotiations, that the ASEAN-China Investment Agreement (hereinafter Investment Agreement) was finally sealed which recalled the related investment objectives drawn in the Framework Agreement. It was delayed mainly because China and the ASEAN were worried about the threat from the foreign direct investment and the sudden flourishing of Chinese investment, respectively. ${ }^{84}$ Most critics blamed China for the sharp decline of the ASEAN FDI inflow; China was said to gain in FDI inflow at the expense of its neighbors. ${ }^{85}$ The ASEAN senior official Mahathir Mohamad complained that China was an economic threat for Southeast Asia in terms of attracting FDI. ${ }^{86}$ Prime Minister Goh Chok Tong of Singapore also reiterated the serious threat that: "Our biggest challenge is therefore to secure a niche for ourselves as China swamps the world with her high quality but cheaper products. ${ }^{, 87}$ In fact, as the 'China threat' has gradually given way to the "China opportunity." ${ }^{, 88}$

Some economist emphasizes that most countries have wrongly responded to the rise of China. ${ }^{89}$ It should be recognized that more than half of the 2003 FDI inflows in China originated from Hong Kong, while 60 percent of FDI of the ASEAN-5 came from developed countries. ${ }^{90}$ Actually, the true extent of FDI flows to China might be smaller than officially declared because of 'round-tripping' FDI inflows. $^{91}$ As the FDI inflow between the ASEAN and China comes from different sources, the FDI inflow of the parties is economically incomparable. ${ }^{92}$

Furthermore, the economic threat posed by China to the ASEAN has been overstated and based on the assumption that it is a zero-sum game where an increase in FDI flows to China takes place at the expense of a corresponding decrease in FDI inflows to the ASEAN. Both parties experienced a serious decline in FDI during the Asian financial crisis. ${ }^{93}$ Therefore, the financial crisis was the real factor behind the FDI drop in the ASEAN, rather than the attractiveness of China's new markets. Additionally, the UNCTAD statistics shows that China (from a 9.24 percent share to 7.9 percent share) and the ASEAN Member States (from a 7.01 percent share to a 4.05 percent share) experienced a decrease in FDI inflow from 1997 to 2005. In contrast, for the same period, FDI inflow of the EU increased from 29.2 percent to 46 percent of global FDI inflow. ${ }^{94}$ 
The sharp decline of FDI in the ASEAN and China may be due to the lack of confidence of investors in the rehabilitation of vulnerable East Asian financial markets after the 1997 crisis. ${ }^{95}$ Besides, the increasingly stable financial market, improved investment infrastructure and constant growth of GDP in China as well as its entry into the WTO, may, to some extent, gradually divert parts of regional FDI flows. ${ }^{96}$ Nevertheless, these diversions were not the decisive factor for the sudden decrease of FDI flows in the ASEAN. Based on the aforementioned statistics and analyses, it appears that many factors may drive the decline of FDI flows in the ASEAN. Therefore, to say that China is a threat to the ASEAN attracting FDI inflow lacks concrete evidence.

\section{B. Liberal, Facilitative, Transparent and Competitive Investment Regime}

Unlike the ACFTA sister agreements, the Investment Agreement does not have the WTO framework rules to follow, but was designed comprehensively in seven parts: Definitions (Article 1), Scope of Application (Article 3), National and MFN Treatments (Articles 4 and 5), Non-Conforming Measures (Article 6), Treatment of Investment (Article 7), Expropriation (Article 8) and Dispute Resolution (Articles 13 and 14). ${ }^{97}$ The Investment Agreement defines the scope of investment using asset-based methods and itemizes movable and immovable property, intangible assets such as copyrights, patents and trademarks, business concessions, ${ }^{98}$ extracting and exploiting natural resources. ${ }^{99}$ With regard to the scope of application, the Agreement would not apply to any tax measures, government procurement-related measures or government-related services. ${ }^{100}$

Most importantly, China and the ASEAN finally reached agreement on the "general treatment of investment," which refers to fair and equitable treatment, full protection and security to investments, and the accordance to investor and investments of national treatment status at post-establishment stage and MFN treatment at both pre-establishment and post-establishment stages. ${ }^{101}$ To date, China has signed nine FTAs, among which seven contain investment provisions. ${ }^{102}$ The post-establishment model is commonly used in a national treatment clause, while the pre- and post-establishment approach is merely adopted in the MFN treatments. ${ }^{103}$ In general, like the structure of investment treatments in the China-New Zealand FTA and the China-Peru FTA, Article 4 of the China-ASEAN Investment Agreement grants national treatment status to 
investors and investments with respect to the "management, conduct, operation, maintenance, use, sale, liquidation or other forms of disposal of investments," while Article 5 accords them more pre-establishment MFN treatments with respect to "establishment, acquisition, expansion, management, conduct, operation, maintenance, use, liquidation." Furthermore, the Investment Agreement also emphasizes that MFN preferential treatments under the existing and future arrangement between the ASEAN members or between any Parties would not be accorded to the ASEAN members or China. ${ }^{104}$ It means no Parties can take advantages of the other Parties' individual trade pact.

The consensus embedded in the China-ASEAN Investment Agreement may help harmonize the Parties' domestic investment laws and policies in terms of market access, national treatment, MFN treatments, scope of application and dispute settlement mechanism. In addition to these internal benefits, this ASEAN +1 initiative may provide a concrete institution for integrating external investments in the regional market.

\section{Dispute Resolution and Settlement}

To ensure the implementation of the Investment Agreement, the ASEAN and China agreed on a dispute settlement mechanism, which is initiated by consultations. Disputes arising from investments in each Party shall be settled either at State-to-State level (Article 13) or at State-to-investor (Article 14) level. With respect to State-to-State investment, disputes between the Parties are captured by the Agreement on Dispute Settlement Mechanism of the Framework Agreement on CEC between the ASEAN and China ("ADSM") on November 29, 2004. ${ }^{105}$ Disputes shall be settled in three ways by: consultation, mediation and arbitration. Among these methods, a request for consultations must be launched first in any matter affecting the implementation or application of the Agreement. ${ }^{106}$ A complainant must submit a request for consultations in writing with the specific measures at issue as well as the factual and legal basis for the complaint. A consultation should be completed within 30 days after the date of receipt of the request in good faith to reach a mutually satisfactory solution. ${ }^{107}$ Likewise, the third party with a substantial interest in a dispute may notify the parties to the dispute in writing of its desire to be joined in the consultations provided the party complained against agrees. ${ }^{108}$ The parties may recourse to or 
terminate conciliations or mediation proceedings at any time upon which they reach agreement. When disputes fail to conclude within 60 days, a disputing party may submit a claim pursuant to arbitration proceedings. ${ }^{109}$ Different from the 2004 ASEAN Dispute Settlement Mechanism, ADSM is a judicial based mechanisms and a novel departure from the 'ASEAN Way' consensus method of dispute settlement. ${ }^{110}$

In case of investment disputes between a Party and an investor, the ChinaASEAN Investment Agreement applies only to an breach of obligation in relation to the management, conduct, operation, sale or other disposition of an investment under Article 4 (National Treatment), Article 5 (MFN Treatment), Article 7 (Treatment of Investment), Article 8 (Expropriation), Article 9 (Compensation for Losses) and Article 10 (Transfers and Repatriation of Profits). ${ }^{111}$ Article 13, paragraph 3 emphasizes the importance of consultation proceedings in which both Parties must first resolve their dispute through a written request for consultations within a limited period of time.

Unlike the general dispute settlement mechanism of the ACFTA, which offers a 30-day time limit for further proceeding to arbitration, ${ }^{12}$ Article 14 of the Investment Agreement provides six months for investors to freely take further actions where the dispute cannot be resolved through consultations. At this stage, the investors can submit a claim to their national courts, tribunals and to international arbitration under the International Centre for Settlement of Investment Disputes Convention or the arbitration under the UN Commission on International Trade Law. ${ }^{113}$ Article 14, paragraph 5 mandates the choice of procedure for investors between an international dispute settlement and a domestic court. This rule is softened, considering that the investor can first file a claim in a domestic court and later submit the case to international dispute settlement provided the investor has withdrawn the case from the domestic court. ${ }^{114}$ In Indonesia, the Philippines, Thailand and Vietnam, once an investor has submitted the dispute to the competent courts or administrative tribunals, the choice of procedure is final.

Due to a shift in comparative advantage between the region and China, and its 'going out' strategy, Chinese enterprises have tended to flood into neighboring Southeast Asian States for overseas investment, which is the most attractive FDI destination for such Chinese enterprises. ${ }^{115}$ In any case, the ASEAN and 
China diverted from the traditional consensus of dispute settlement method and developed a less diplomatic system in the strategic regionalism that is signified as bilateral investment agreement beyond the present WTO system. The ASEANChina Investment Agreement has made remarkable progress in liberalizing investment sectors, formalizing dispute settlement mechanism and offering a facilitative and transparent investment mechanism for investors and investment from both sides

\section{Hedging But Engaging Rising China}

\section{A. Suspicion of China's Generosity}

For more than a century China has largely moved away from the traditional world order which it has endeavored to reintroduce in this decade, with its fast growing economic and political strength. In particular, China's active and sudden promotion of regional cooperation in Southeast Asia has brought uncertainty and suspicion to its neighbors. Is contemporary China a threat or an opportunity? China has re-emerged and maintained its external security by means of economic inducement and concessions. Nevertheless, its resurgence comes at a price. This is inextricably related to the extent to which China can meet the hostilities of Southeast Asian States and adopt the diplomacy of benevolence and reciprocity.

The China-ASEAN free trade area is driven by political and economic incentives, while China's security maneuver is obtained at the expense of economic concessions. The ASEAN might continue to tango with China and embrace other extra-regional powers to balance and to enhance its regional role as a primary driving force. ${ }^{116}$ Indeed, China might sometimes push too fast and cause discomfort to many ASEAN members by giving excessive benefits to the ASEAN or placing the ASEAN on the hub of the Chinese market and Sino-foreign relations. ${ }^{117}$ From the tariff privileges initiated in the EHP, to the unprecedented openness in the sectors of services and investment, China has offered a serial commercial concession to secure its good relationship with the ASEAN and to buy neighboring States off. In this way, a China-ASEAN free trade area could in part help to reduce political hostilities in Southeast Asia and to forge a stable and friendly community that could guarantee China's peaceful ascendancy. 
China's recent trend towards regionalism with Southeast Asia has stimulated Korea, Japan and many other countries in East Asia; they began negotiating their own free trade initiatives soon after the Framework Agreement. ${ }^{118}$ Beijing's diplomacy would show the Chinese leaders' latitude on quelling the ASEAN's concerns about China's economic and political influence. Even before the China's recent leadership transition, Chinese President Xi Jinping attended the ASEANChina Expo on September 21, 2012 to reassert the significance of China-ASEAN relations despite their territorial conflicts and economic challenges. ${ }^{119}$

\section{B. Transformation of a Zero-sum Game into a Win-Win Cooperation}

Since the ACFTA, the political clashes between the ASEAN and China have been decreasing. Now, another aspect of the ASEAN anxiety over China's rise is associated with China's preponderance in the market, resource exploitation and lack of governance over outward investment. ${ }^{120}$ In order to transform the ASEAN economic structure and to deepen its regional integration, it might be necessary for the ASEAN to adjust their stance, recognize the Chinese position and identify the complementary and comparative advantages. In addition, it is likely that there would be 'adjustment costs' for Southeast Asian countries in the face of China's on-going growth. ${ }^{121}$ When China has moved up its technological ladder to maintain a complementary relationship in the Asian production chain and turn these threats into opportunities, the ASEAN will have to adjust through technology transfers and restructuring their respective economies. ${ }^{122}$ It was suggested that the ASEAN should shift its competition with China to the cooperation in product and service quality, efficiency and comparative advantages. ${ }^{123}$ E.g., the ASEAN possesses distinctive advantages over China with regard to mineral and petroleum resources, technology-intensive products, timber and paper products. ${ }^{124}$ Comparative advantages can be also found in the availability of agricultural raw materials, which present a great potential for trade between the ASEAN and China. ${ }^{125}$

Nevertheless, the comparative advantage can only help to explore horizontal production advantages rather than create a vertically integrated production network, and to deepen the ASEAN-China economic integration in the long run. The other alternative is that the ASEAN could invest in and profit from the huge Chinese domestic market that has been created by China's rapid economic growth. As China further liberalizes its service and investment sector by signing a 
sequence of FTAs with the ASEAN, Southeast Asian investors have exploited the advantages of liberalization based on their indigenous technology and historical bonds. ${ }^{126}$ This is particularly true in the service sector, including outbound tourism. ${ }^{127}$ In a survey of utilization rates of FTAs in China and the ASEAN, 65.7 percent of the firms that agreed to be interviewed were willing to use the preferential tariff agreement under the ACFTA. ${ }^{128}$ The usage rate might imply the trend of businesses to aim at outsourcing the investment costs, goods and service in cross-border markets between the ASEAN and China. For the ASEAN members, it would be pragmatic to engage in the transformation of their own domestic economic structures by seeking opportunities to complement each other in the new production chain because the growth of China is positively linked with that of other Asian States. ${ }^{129}$ As such, the strong geopolitical and cultural sentiments as well as the increasing bilateral investments may overwhelm the fears of Southeast Asia States and help them to be the first taste to an East Asian economic revival.

Security and regionalism are intrinsically correlated, and the tensions and conflicts arisen from these factors offer an insight into the impacts and consequences of growing Chinese power and influence on Southeast Asia States. The question may arise whether the strategies and policies of China-led regionalism can succeed in addressing most serious political and economic threats confronting the ASEAN-China relations. Above all, a key concern in coping with the re-emergence of China for its neighbors, is to look for ways of complementing China through preferential access to the Chinese market under the framework of the ACFTA.

\section{Conclusion}

It is not clear whether Southeast Asia States can hitchhike onto China's fast economic growth or whether China will revive the Chinese MFN diplomacy deriving from the ancient tribute system by creating her own regional regimes as well as developing a variant to the general WTO rules. The ASEAN remains skeptical about the unilateral trade concessions and huge trade deficits given by China in the three agreements on trade concluded since 2003. Apart from this, 
the pioneering and substantial product coverage are prevailing in the region, particularly applying the wide range of liberalization on goods, services and investment as well as a comprehensive State-to-investor dispute resolution in the investment sector. The ACFTA could be an outcome of the WTO framework especially when the ASEAN-China integration fails to mitigate the impacts of China's arrival on increasing economic capabilities and political influence. Nevertheless, the framework agreements pave the way for an enduring peace in East Asia. It is therefore not difficult to comprehend the sincerity of engagement with each other in the regional dialogue.

In the future, the ASEAN might keep going with China for their geopolitical security and China's huge domestic market. At the same time, the ASEAN will carefully watch China's movement while retaining its good relationship with the US and Japan. It is noted that there are three contentious concerns against the ASEAN-China friendship as follows: (1) overlapping territorial disputes in the South China Sea; (2) China's competitive status in the global economy; and (3) China's strategic intentions. ${ }^{130}$ China, a growing regional and world power, is expected to project its 'soft power,' to reduce its 'threat,' and to secure friendships with the ASEAN through normative institutions providing economic, financial and technological assistance across Southeast Asia.

Beijing is thus actively involved in building the ASEAN and the foundations of the East Asian Community in the ongoing construction of the GMS rail network, dams, bridges and highways. ${ }^{131}$ Unconditional regional assistance can indeed consolidate mutual trust with the ASEAN countries in the short term, but substantial economic cooperation based on the complementary advantages of the ASEAN-China industry and a high level of institutionalization in the ACFTA should be a priority on the agenda of China's long-term strategy.

\section{REFERENCES}

1. Framework Agreement on Comprehensive Economic Co-operation between ASEAN and the People's Republic of China, art. 1. It underscores that: "The objects of the Agreement are to strengthen and progressively liberalize economic, trade and investment cooperation between the parties."

2. Yunling Zhang, The Impact of Free Trade Agreements on Business Activity: A Survey of Firms in the People's Republic of China, (ADB Institute Working Paper, No. 5, 2010), available at $\mathrm{http}: / / \mathrm{www} . a d b . o r g /$ publications/impact-free-trade-agreements-business-activity- 
survey-firms-peoples-republic-china (last visited on Aug. 1, 2015).

3. A. Maierbrugger, China-ASEAN Trade Forecast to Hit $\$ 500$ b by 2015, INVESTVINE, July 24, 2013, available at http://investvine.com/china-asean-trade-seen-to-hit-500b-by-2015 (last visited on Aug 6, 2015).

4. A. Ba, China-ASEAN Relations: The Significance of an ASEAN-China Free Trade Area, in China Under Hu Jintao: Opportunities, Dangers, and Dilemmas 347 (Tun-jen Cheng, J. Delisle \& D. Brown eds., 2005). Ba reveals that China aims to impress the ASEAN and sustains China-ASEAN good relations by paying numbers of high-profile diplomatic visits.

5. Zhengang Ma et al., The CiIS Bluebook on International Situation and China's Foreign AFFAIR [国际形势和中国外交报告 2008-2009] 285 (2009). <available only in Chinese>

6. Supra note 2, at 5.

7. ASEAN Secretariat, Top ten export markets and import origins 2009, available at http:// www.asean.org/archive/stat/Table21.pdf (last visited on Aug. 1, 2015).

8. China Customs Statistics, Statistics available from year 2011 to 2008 on its official website, available at http://www.chinacustomsstat.com/aspx/1/NewData/Stat_Data.aspx?state=3\& month $=12$ \&year $=2011$. The pattern of bilateral trade between China and the ASEAN has changed since 2012 in which China had trade surplus of USD 8.5 billion with the ASEAN. It was dropped to USD 6.3 billion in 2014, available at http://news.xinhuanet.com/english/ china/2013-07/23/c_132566755.htm; http://info.hktdc.com/hktdc_offices/mi/ccs/index_ static_type/ImportsbyCountryofOriginFinalDestinationim.htm; http://info.hktdc.com/hktdc offices/mi/ccs/index_static_type/ExportsbyCountryofOriginFinalDestinationex.htm; (all last visited on Aug. 1, 2015).

9. Supra note 4, at 320 .

10. Lijun Sheng, China's Economic Relations with ASEAn: Developments and Strategic Implications, in Asean-China Economic Relations 295 - 317 (2007).

11. Tieya Wang, International law in China: historical and contemporary perspectives, in RECUEIL Des Cours II 221-2 (1990). See also J. Fairbank, The Chinese World Order: Traditional China's Foreign Relations, in A Preliminary Framework' in John King Fairbank 4 (J. Fairbank ed., 1968).

12. Wang $i d$. at 215-6. He points out that the relations mainly reflects a typical Chinese family relations that China acts as a parent and the other countries in the world obeys as its children.

13. Id. at 219 .

14. D. Kang, East Asia Before the West 55-6 (2010).

15. Dongyang Li et al., 180 Da Ming Hui Dian [大明会典] (Codes of Great Ming Dynasty, Translation Added) 1616 and 1625 (revised by Shixing Shen, 1989). <available only in Chinese $>$ One of the rules in the system is that most countries in Southeast Asia should pay the tributes in every three years, and can only exchange the goods from the tribute ship with Chinese authority three days or five days after receiving imperial gifts from the Emperor in Beijing. 
16. Jinfan Zhang \& Xiaofeng Huai, 7 The History Of Chinese Legal System [中国法制史] 378 (1999). <available only in Chinese>

17. Id. at 380 .

18. Supra note 15, vol. 111, at 1648.

19. Jiangyu Wang, China's Regional Trade Agreements: The Law, Geopolitics, and impact on the Multilateral Trading System, 8 Sing. Y.B. INT'L L. 119-47 (2004).

20. The free trade agreement is not limited to trade in goods, services and investment but with other areas of cooperation such as intellectual property rights, technology transfer, trade facilitation, tourism and sub-regional development.

21. "China shall accord Most-Favoured Nation Treatment consistent with WTO rules and disciplines to all the non-WTO ASEAN Member States upon the date of signature of this Agreement." At the time of signing the Framework Agreement, Cambodia, Laos and Vietnam were non-members of the WTO. Cambodia became a member of the WTO on October 13, 2004, Vietnam on January 1, 2007, Laos became a member on February 2, 2013

22. The ASEAN and China signed the Memorandum of Understanding on Agricultural Cooperation on January 14, 2007, and the Memorandum of Understanding in Intellectual Property on December 21, 2009. On January 1, 2011, the Second Protocol to amend the TIG Agreement addressed particularly the operation of Form E to further facilitate the trade between the Parties.

23. In Indonesia, Chinese accounted for 3\%-4\% of the population and owned about $70 \%$ of the private domestic capital. See Ching-Hwang Yen, The Chinese in Southeast Asian and Beyond Socioeconomic and Political Dimensions 321-2 (2008).

24. Chen Qi Yuan (1825-1905), ethnic Chinese, established the first filatures Industry in Guang Dong Nanhai Country. See Seung-Joon Lee, Gourmets in the Land of Famine: The Culture and Politics of Rice in Modern Canton 78 (2011). The Nanyang Chinese also made significant financial contribution to the 1911 Revolution in China, which was lead by Dr. Sun Yat-sen. Yen, id. at 376.

25. Supra note 10, at 295.

26. Id. at 3.

27. Jiangyu Wang, The International Legal Personality of ASEAN and the Legal Nature of the CAFTA, in China-ASEAN Relations: Economic And Legal Dimensions 111-32 (J. Wong, Keyuan Zou \& Huaquan Zeng eds., 2006).

28. Chai Mee Lim \& M. Yeoh, ASEAN-China Free Trade Area: Charting a new Era of Regional Cooperation in East Asia and Southeast Asian, in Globalisation AND Impact on Asia: SHaring Knowledge, IdeAs and Information 19-30 (Michael Yeoh et al. eds., 2003).

29. Supra note 4, at 321. Four key bilateral agreements have been concluded between China and the ASEAN in the productive year of 2002 as follows: the Joint Declaration on Cooperation in the Field of Non-traditional Security Issues; the Declaration on Conduct in the South 
China Sea, the Framework Agreement on Comprehensive Economic Cooperation; and the Memorandum of Understanding on Agricultural Cooperation

30. Keyuan Zou, China-Asean Relatons and Internatonal Law 71 (2009).

31. ACFTA Framework Agreement art. 8.

32. Id. pmbl.

33. Thitapha Wattanapruttipaisan, ASEAN-China Free Trade Area: Advantages, Challenges and Implications for the Newer ASEAN member Countries, 20 ASEAN ECON. BuLL. 31-48 (2003). The tariff rates for machinery and equipment dropped from 13.4 to 6.6 percent, and the tariff rates for Motor vehicles were decreased from 31.3 to 1.1 percent.

34. Haibing Zhang, China's Aid to Southeast Asia, in ASEAN-China Economic Relations 250-68 (Swee-Hock Saw ed., 2007). China has heavily engaged in building the BangkokKunming highway in Southeast Asia by providing USD 2.49 million interest-free loans and grants.

35. Eric Teo Chu Cheow, Paying tribute to Beijing: An ancient model for China's new power, N.Y. Times, Jan. 21, 2004, available at http://www.nytimes.com/2004/01/21/opinion/21ihtedteo_ed3_html (last visited on Aug. 2, 2015).

36. ACFTA Framework Agreement art. 1.

37. Id. pmbl. \& art. 3

38. The ASEAN-China Expert Group on Economic Cooperation, Forging Closer ASEAN-China Economic Relations in the Twenty- First Century, Oct. 2001, available at http://www.asean. org/archive/asean_chi.pdf(last visited on Aug. 2, 2015).

39. Article 6 of the ACFTA Framework Agreement identifies that the duties and other restrictive regulations of commerce under the GATT are modification of commitments, safeguard actions, emergency measures and other trade remedies, including anti-dumping and subsidies and countervailing measures.

40. ACFTA Framework Agreement arts. 2(a) \& 3(4)

41. Id. Annex 3.

42. Qingjiang Kong, China's WTO Accession and the ASEAN-China Free Trade Area: the Perspective of Chinese Lawyer 7 J. InT'L Econ. L 853 (2004).

43. These products are live animals, meat and edible, meat offal, fish, diary produce, other animal products, live trees, edible vegetables, edible fruits and nuts. See ACFTA Framework Agreement art. 6(3). See also supra note 2.

44. N. Fold, J. Neilson \& B. Pritchard, Being Sandwiched: The Reshaping of ASEAN-China Food Trade, in ASEAN Industries and the Challenge from China 180-209 (D. Jarvis \& A. Welch eds., 2011).

45. Id. at 186-7. Since the EHP took effect on October 2003, Thailand has enjoyed USD 800 million trade surplus to China. The primary beneficiary of the Thai-China agreement is Charoen Pokphand Group, which fruit trade increased tenfold to USD 2.6 million annually from 2003 to 2005 . 
46. Dazhi Wei, The History of Economic Development in ASEAN Ten Members [东盟十国经济 发展史](600 (2010).

47. Article 6(3)(a)(i) of the ACFTA Framework Agreement stipulates that unless the products are covered in the exclusion list of Annex 1 of the Framework Agreement, all the products in the 8 chapters would be incorporated by the EHP. See Jiangyu Wang, Association of Southeast Asian Nations-China Free Trade Agreement, in Bilateral and Regional Trade Agreements: Case Studies 192-225 (S. Lester \& B. Mercurio eds., 2008).

48. S. Inama, The Association of South East Asian Nations -People's Republic of China Free Trade Area: Negotiating Beyond Eternity with Little Trade Liberalization? 39 J. WorLD TRADE 559-79 (2005).

49. ACFTA Framework Agreement art. 3(6).

50. Agreement on Trade in Goods of the Framework Agreement on Comprehensive Economic Co-operation between the Association of Southeast Asian Nations and the People's Republic of China (hereinafter TIG Agreement) (Nov. 9, 2004) art. 2.

51. Article 4 of the TIG Agreement refers to the principle of Transparency and Article 12 covers the general exceptions in the module of WTO. Meanwhile, Article 7 underlines the relevant WTO provisions referred to in this Agreement.

52. Id. arts. 9(2) \& (7). The transitional period for the products begins from the date of entry into force and ends five years from the date of completion of tariff elimination for that product.

53. Id. art. 9(2). See also WTO Agreement on Safeguards arts. 2 \& 7.

54. Wang, supra note 11, at 205.

55. TIG Agreement art. 9(11).

56. Under Article 16 of the Protocol, products that are originated from China in the transitional period (12 years) and caused the market disruption of any WTO Member in a specific amount shall subject to WTO safeguard measures. See Protocol on the Accession of the P.R. China, Nov. 23, 2001, WT/L/432.

57. Accession Agreement of China to the WTO, § 15(a). It reads: "In determining price comparability under Article VI of the GATT 1994 and the Anti-Dumping Agreement, the importing WTO Member shall use either Chinese prices or costs for the industry under investigation or a methodology that is not based on a strict comparison with domestic prices or costs in China based on the following rules."

58. Id. $§ 15(\mathrm{a})(\mathrm{i})$.

59. D. Irwin, Free Trade Under Fire 116 (2002).

60. Id. at 125-7.

61. I. Neufeld, Anti-dumping and Countervailing Procedures -Use or Abuse? Implication for Developing Countries, in Policy Issues in International Trade and Commodities Study Series No.9, UNCTAD/ITCD/TAB/10 (2001), available at http://unctad.org/en/docs/itcdtab10_ en.pdf (last visited on Aug. 2, 2015).

62. China makes breakthrough in market economy status, XINHUANET, Apr. 15, 2004, available 
at $\mathrm{http}: / /$ news.xinhuanet.com/english/2004-04/15/content_2033245.htm (last visited on Aug. 2, 2015).

63. Up to 2006, there were 66 countries including Malaysia, New Zealand, Singapore, Brazil, Egypt, Argentina and Chile which had extended the MES to China. See 66 Countries Recognize China's Market Economy Status, Xinhuanet, Jan. 15, 2007, available at http:// www.china.org.cn/business/2007-01/15/content_1196040.htm (last visited on Aug. 2, 2015).

64. E. Ianchovichina \& T. Walmsley, Impact of China's WTO Accession on East Asia, in World Bank Policy Research Working Paper Series No. 310916 (2003), available at http://siteresources.worldbank.org/INTDEBTDEPT/Resources/4689801206974166266/4833916-1206974192224/PRWP3109.pdf (last visited on Aug. 5, 2015).

65. Shandre Thangavelu, Will ASEAN benefit from the ASEAN-China FTA? EAST AsIA F., Jan. 27, 2010, available at http://www.eastasiaforum.org/2010/01/27/will-asean-benefit-fromthe-asean-china-fta (last visited on Aug. 2, 2015).

66. TIS Agreement, pmbl, available at http://fta.mofcom.gov.cn/topic/chinaasean.shtml, (last visited on Aug. 19, 2015). It reads: “...progressively eliminate all discrimination with respect to trade in services and to expand the depth and scope of sectoral coverage beyond the WTO General Agreement on Trade in Services (GATS)."

67. Media Statement of TIS Agreement, Jan. 14, 2007, available at http://www.asean.org/ news/item/external-relations-china-media-statement-on-asean-china-agreement-on-trade-inservices (last visited on Aug. 2, 2015).

68. Id.

69. TIS Agreement art. 7.

70. At the time of signing the TIS Agreement, Laos was not a member of the WTO. But China extended MFN treatment to Laos.

71. TIS Agreement art. 1(t).

72. Id. art 5(4).

73. There are 11 schedules of specific commitments under the first package of commitments of the ASEAN-China TIS Agreement, available at http://www.thaifta.com/trade/china/sc1_ prc.pdf (last visited on Aug. 2, 2015).

74. FTA partner only obligated with the items listed in the positive lists which usually contain four-modes of specific commitment, description of sector or sub-sector committed, limitation of market access, and limitation of national treatment. The service which is not found in the schedule cannot benefit from the FTA. The negative list covers exceptions to the commitment, in which service are fully committed unless indicated. It usually covers the provision entitled reservations. Service Agreements such as the ASEAN-Korea FTA, Thailand- Australia FTA, EFTA - Singapore, China-Singapore FTA adopt positive lists approach. Singapore-Australia FTA applies negative list schedule. See R. Adlung \& H. Mamdouh, How To Design Trade Agreements in Services: Top Down or Bottom Up?, WTO 
Economic Research And Statistics Division Staff Working Paper ERSD-2013-08, available at https://www.wto.org/english/res_e/reser_e/ersd201308_e.pdf (last visited on Aug. 2, 2015).

75. TIS Agreement art. 22. See also the Parties' schedule of specific commitments, available at http://fta.mofcom.gov.cn/topic/chinaasean.shtml (last visited on Aug. 2, 2015).

76. ADB, How to Design Negotiate and Implement a Free Trade Agreement in Asia 58-9 (2008).

77. TIS Agreement art. 21(4). It reads that the schedules of specific commitment of a Party shall apply only to those Parties which have completed their respective schedule of specific commitments through negotiations.

78. China, Laos and Myanmar have not placed specific commitment in tourism sector in the first package.

79. See Sector-specific section of the Philippines Schedule of Specific Commitment of ASEANCHINA Agreement on Trade in Services, Annex 1/SC1, available at http://fta.mofcom.gov. $\mathrm{cn} /$ dongmeng/annex/flb_chengruo_en.pdf (last visited on Aug. 2, 2015).

80. Id. See also Indonesia Schedule of Specific Commitment Pt. II, available at http://fta. mofcom.gov.cn/dongmeng/annex/yindunixiya_chengruo_en.pdf (last visited on Aug. 2, 2015).

81. TIS Agreement art. 22.

82. R. Maclean, EU Trade Barrier Regulation: Tackling Unfair Trade Practices 43 (2006).

83. TIS Agreement Annex 1. There are three services sectors, namely real estate services, computer and related services, and recreational, cultural and sporting services where wholly foreign-owned enterprise will be allowed.

84. The Investment Agreement was expected to be signed in December 2008, but was finally concluded in August 2009. See ASEAN, China make substantive progress on investment pact, XinhuANET, Aug. 28, 2008, available at http://news.xinhuanet.com/english/2008-08/28/ content_9777136.htm (last visited on Aug. 6, 2015)

85. D. Das, Foreign Direct Investment in China: Its Impact on the Neighboring Asian Economies, 6 Asian Bus. \& Mgmt. 285-301 (2007).

86. See Beijing Economic Not Military Threat: Mahathir, The China Post, May 22, 2002, available at http://www.chinapost.com.tw/news/2002/05/22/26697/Beijing-economic.htm (last visited on Aug. 6, 2015).

87. See Singapore unveils new economic plan, Int'l Herald Tribune, Aug. 21, 2001, available at http://www.singapore-window.org/sw01/010821ih.htm (last visited on Aug. 2, 2015).

88. S. Pushpanathan, Building an ASEAN-China Strategic Partnership, JAKARTA Post, July 1, 2004, available at http://www.asean.org/resources/item/building-an-asean-china-strategicpartnership-opinion-and-editorial-by-s-pushpanathan-for-the-jakarta-post (last visited on Aug. 2, 2015).

89. M. Plummer, ASEAN Economic Integration 40 (2009). 
90. Wen Chen, Are China and ASEAN Competing for FDI? in China-ASEAN Relations: Economic And Legal Dimensions 199-218 (J. Wong, Zou Keyuan, Zeng Huanquan eds., 2006).

91. Friedrich Wu, et al., Economics Division. Ministry of Trade and Industry, Foreign Direct Investments to China and Southeast Asia: Has ASEAN Been Losing out?, ECONOMIC SURVEY OF SingaPORE (2002), available at http:/unpan1.un.org/intradoc/groups/public/documents/ apcity/unpan010347.pdf (last visited on Aug. 2, 2015). Round-tripping is a widely known strategy undertaken by Chinese enterprises in moving a large proportion of their funds to other countries, mainly Hong Kong and the Caribbean tax-free zone, which is subsequently returned to China as 'new FDI,' to take advantage of preferential tax treatment.

92. Supra note 89 , at 38 .

93. A. Acharya, Seeking Security in The Dragon's Shadow: China and Southeast Asia in the EMERGing Asian ORDER 8-9 (2003).

94. Supra note 89 , at 39.

95. Supra note 93, at 9. Acharya reveals that the zero-sum presumption of the China-ASEAN that increased FDI flows to China at expense of the ASEAN has been questionable as the decline of FDI in the Association may not be contributed by the growing attractiveness of China, but by the fallout of the Asian economic crisis, such as investor confidence in Southeast Asia. See also J. Ravenhill, Is China an Economic Threat to Southeast Asia? 46 Asian SuRvey 653-74 (2006). Ravenhill points out that the fundamental problem with the argument that much of regional FDI has been diverted from the ASEAN in favor of China is the assumption that the total amount of FDI in the global economy at any given time is fixed. Whereas, the assumption is essentially the fallacy that the overall amount of global FDI is in no way constant.

96. Busakorn Chantasasawat, et al., Foreign Direct Investment in East Asia and Latin America: Is there a People's Republic of China Effect?, ADB Institute Working Paper No.28 (Dec. 2004), available at http://www.adb.org/publications/foreign-direct-investment-east-asiaand-latin-america-there-peoples-republic-china-0 (last visited on Aug. 8, 2015). The econometric studies have demonstrated that the 'PRC effect' is not the most important determinant of the inflows of FDI into these economies including the ASEAN members. They also suggested that the 'PRC effect' had a positive effect on Southeast Asian economies. See Ravenhill, id. It is likely that an increase of FDI flows to China is attribute to China's accession to the WTO and improvement of investment policies.

97. Agreement on Investment of the Framework Agreement on Comprehensive Economic Cooperation between ASEAN and China, available at http://fta.mofcom.gov.cn/inforimag es/200908/20090817113007764.pdf (last visited on Aug. 2, 2015).

98. Business concessions include contractual rights such as those under turnkey, construction or management contracts, production or revenue sharing contracts, concessions, or other similar contracts and can include investment funds for projects. See Investment Agreement n. 
2.

99. Id. art $1(\mathrm{~d})$.

100. Id. art. 3(4).

101. For details on the two models of obligation presented in international investment agreement which limits rights to investor and investments in some sectors, see A. Newcombe \& L. Paradell, Law And Practice Of Investment Treaties: Standards Of Treatment 133-5 (2009).

102. In China-Switzerland FTA, the parties merely agreed the investment promotion rules without touching the preferential investment provision. The China-Singapore FTA does not contain investment rules. As of 2015, there are nine FTA in force, including the ACFTA, China-Chile FTA, China-Singapore FTA, China-Pakistan FTA, China-New Zealand FTA, China-Peru FTA, China-Costa Rica FTA, China-Iceland FTA and China-Switzerland FTA. See the official website of the P.R. China Ministry of Commerce, available at http:// fta.mofcom.gov.cn/topic/enpakistan.shtml (last visited on Aug. 2, 2015).

103. Chapter IX of China-Pakistan FTA provides only the general treatment of investment for post-establishment National Treatment. As for the investment treatment, Article 92 of the China-Costa Rica FTA simply stipulates National Treatment in a post-establishment phase without mentioning the MFN treatment.

104. Investment Agreement art. 5(3).

105. Agreement on Dispute Settlement Mechanism of the Framework Agreement on Comprehensive Economic Co-Operation Between the Association of Southeast Asian Nations and the People's Republic of China, Nov. 29, 2004 (hereinafter Dispute Settlement Mechanism Agreement), available at http:/www.asean.org/images/2013/economic/afta/ ACFTA/4-\%20ACFTA\%20DSM\%20legal\%20text.pdf (last visited on Aug. 2, 2015).

106. Dispute Settlement Mechanism Agreement art. 4(1).

107. Id. 4(3).

108. Id. art. 4(6).

109. Id. art. 6(1). Time limit for initiating arbitration in the ACIA is 180 days. See id. art. 32.

110. F. Snyder, China, Regional Trade Agreements and WTO Law 43 J. World Trade 1-57 (2009).

111. Investment Agreement art. 13(1).

112. Dispute Settlement Mechanism Agreement art. 4(3).

113. Investment Agreement art. 14, $₫ 4$.

114. Jun Xiao, The China Investment Agreement, A Regionalization of China's BITs, 1 Frontiers L. China 241-58 (2011)

115. J. Wong \& S. Chan, China's Outward Direct Investment: Expanding Worldwide, 1 ChInA: An Int. J 273-301 (2003).

116. The figure of massive trade deficit shown above might lead a perception about China is attempting to maintain and buy its friendship from the ASEAN by sacrificing its trade deficits to underpin the balance in East Asia. 
117. China has eliminated its tariffs for most products from Laos, Cambodia and Myanmar since 2004, and launched the "Asia Debt Reduction Plan" to decrease or wipe debts of the CLMV. See Haibing Zhang, China's Aid to Southeast Asia, in ASEAN-China Economic Relations 260 (Swee-Hock Saw ed., 2007). Ba reveals that the the ASEAN's decision to accept the agreement reflects a sense of inevitability about taking a ride on the growth of China at the same time being compete with China in their domestic market, which might influence the ASEAN's strategic balance in their economic and political ties with all interested powers, such as keeping alliance with Washington. See supra note 4, at 336-7 $\& 346$. This sense of inevitability and a fear of being left behind is essentially a sense of economic insecurity or a sense of discomfort which would not be substantially changed by China's excessive concessions on trade arrangement in a short period of time. See also supra note 28 , at 20.

118. A year after that ACFTA was signed, Japan launched the Framework for Comprehensive Economic Partnership between the ASEAN and Japan. Then, the ACFTA has been applied to the later ASEAN+Korea mechanism in the 2006 Agreement on Trade in Goods, and the ASEAN+Japan in the 2008 Comprehensive Economic Partnership Agreement.

119. Cheng Zhao, et al., Vice-President Xi attending the Open Ceremony of Ninth ASEANChina Expo and visiting the pavilion, PeOPLE, Sept. 21, 2012, available at http://politics. people.com.cn/n/2012/0922/c1024-19077951.html (last visited on Aug. 2, 2012).

120. Supra note 10, at 303-8.

121. The ASEAN countries could move away from the traditional export-oriented strategies as the main engine for economic growth, explore their specialties and produce higher value goods by supporting domestic enterprises that use indigenous skills and resources.

122. Beoy Kui Ng, The Economic Emergence of China, in Connecting and Distancing Southeast Asia And China 198-99 (Khai Leong Ho ed., 2009).

123. Yue-Man Yeung, The Pan-PRD and ASEAN-China FTA as Agent of Regional Integration in Pacific Asia, 6 (Shanghai-Hong Kong Development Institute and Hong Kong Institute of Asia-Pacific Studies eds., 2006) .

124. Id. at 6-7.

125. For details, see Patarapong Intarakumnerd, Thaksin's Legacy: Thaksinomics and Its Impact on Thailand's National Innovation System and Industrial Upgrading, 3 J. InT'L L. \& Bus. 45 (2011).

126. In 2010, direct investment from the ASEAN countries to China reached USD 6.32 billion, a 0.7 billion increase in value than 2008. See China's direct investment to ASEAN countries reached \$2.5 billion, XINHUANET, Mar. 2, 2011, available at http://www.chinadaily.com. cn/business/2011-03/02/content_12104984.htm; China Wants to Boost Cooperation with ASEAN Countries through FTA, available at http://www.business-in-asia.com/asia/china fta.html (all last visited on Aug. 2, 2015).

127. Tourism in China is another business opportunities for the ASEAN. According to the 
ASEAN Secretariat, in 2010, the ASEAN received almost 5.4 million tourists arrivals from China with a growth of 28.9 percent compared with 2009. See ASEAN Secretariat, ASEAN-China Review Dialogue Relations and Cooperation, available at http://www. asean.org/news/asean-secretariat-news/item/asean-china-review-dialogue-relations-andcooperation (last visited on Aug. 2, 2015).

128. Supra note 2, at 14-5.

129. Plummer arrived at the conclusion that a 10 percent increase of FDI flows to China will lead to a 2-3 percent increase of FDI in other Asian States. See supra note 89, at 40.

130. R. Severino, Southeast Asia in Search of an ASEAN Community 290 (2006).

131. Eric Teo Chu Cheow, Strategic Dimensions of ASEAN-China Economic Relations, in ASEAN-China Economic Relations 318-38 (Swee-Hock Saw ed., 2006). 